\title{
Physical and mechanical properties of particleboard bamboo waste bonded with urea formaldehyde and castor oil based adhesive
}

Ivaldo De Domenico Valarelli, Rosane Ap. Gomes Battistelle, Marcus Antonio Pereira Bueno,Barbara Stolte Bezerra,

Cristiane I. de Campos, Manoel C. de S. Alves

\author{
Universidade Estadual Paulista “Júlio de Mesquita Filho" (UNESP) - Faculdade de Engenharia de Bauru (FEB) \\ Programa de Pós-Graduação em Engenharia de Produção \\ Av. Eng. Luiz Edmundo C. Coube, 14-01, Bairro Vargem Limpa, Bauru, São Paulo, Brasil. Telefone (14) 3103-6000. \\ e-mail: rosane@feb.unesp.br \\ Universidade Estadual Paulista "Júlio de Mesquita Filho" (UNESP) - Faculdade de Engenharia Industrial Madeireira, \\ Brasil.
}

\begin{abstract}
This study evaluated the physical and mechanical characteristics of particleboards made of bamboo waste from the species Dendrocalamus giganteus bonded with two different types of adhesives: urea-formaldehyde (UF) and a castor oil based adhesive (M). Thus, eight types of particleboards were produced in the proportions of $6 \%, 8 \%, 10 \%$ and $12 \%$ for each adhesive. The results showed that particleboards produced with UF and $\mathrm{M}$ adhesives had acceptable behavior for physical tests according to the Brazilian standard NBR 14810. The results attained in mechanical tests (MOR and MOE), for all particleboards, were below the requirements for structural usage. This indicates that the residue of bamboo is a feasible raw material alternative for particleboards produced for non structural purposes, such as liners, partitions and other uses for internal seal. Regarding the adhesives, the particleboards produced with UF particleboards showed superior results for both physical and mechanical characteristics, when compared to M particleboards with the same percentage of adhesive.
\end{abstract}

Keywords: particleboard, recycle materials, composites, adhesives, castor oil based adhesive

\section{INTRODUCTION}

The activities of forestry industry generate a significant volume of waste which can be reused or recycled [1, $\underline{4,17] . ~ T h e ~ r e c y c l i n g ~ o f ~ w a s t e ~ f r o m ~ t h i s ~ s e c t o r ~ p r e s e n t s ~ a ~ v i a b l e ~ a l t e r n a t i v e ~ t o ~ p r e v e n t ~ t h i s ~ v a l u a b l e ~ r a w ~ m a t e-~}$ rial to have an inappropriate final disposal in landfills, which can cause negative environmental consequences $[1,17]$.

Due to the growing scarcity of wood and the increasing consumption of wood products, some authors $[8, \underline{9}$, $10,17,18]$ comment that the replacement of solid wood particles for other kind of raw materials for production of particleboard, MDF and plywood is inevitable. The lignocellulosic fibers, such as shell, rice straw, bagasse from sugar cane and bamboo wastes, derived from agriculture can be easily transformed into particles which resemble the particles of wood fibers and may be used as raw material.

Therefore, many researches $[9,10,17]$ have been developed for the use of industrial waste in the production of particleboards for various purposes, such as the use of natural fiber composite boards, liners and prefabricated components. The use of particleboards manufactured with waste has other advantages in comparison to the use of massive wood: the elimination of anisotropy effects, since the particleboards have similar resistance across the width and length; elimination of resistance reducers factors; control of physical and mechanical properties through the variables of the process, such as adhesive, particle geometry, production cost; resistance to fire; and durability [6].

The quality of the particleboards $[8,11,13]$ is a function of previous studies about combinations of the variables (particle size, adhesive content, humidity, etc.) and processes used to produce them. The selection of raw materials should be made based on evaluation of their physical and mechanical properties, as well as, their 
potential for providing large quantities for industrial scale production.

The most common adhesive used in the wood industry is the urea-formaldehyde (UF) and phenol formaldehyde (PF). These adhesives release, during the drying process, toxic gases to human health, which may counteract the beneficial environmental effect $[17,20]$. Therefore, studies of new adhesives have been performed to replace the UF adhesives, such as castor oil based adhesive (M).

This study aimed to produce and evaluate the physical and mechanical properties of eight types of particleboards produced with bamboo residues (from furniture and appliances manufacture) of Dendrocalamus giganteus, using two types of adhesive: urea-formaldehyde and a castor oil based adhesive (Ricinus communis); in the proportions of $6 \%, 8 \%, 10 \%$ and $12 \%$ based on the dry weight, in order to compare the performance and applicability of these adhesives and bamboo residues.

\section{MATERIALS AND METHODS}

\subsection{Materials}

To develop this work, it was used residues from Dendrocalamus giganteus, removed from stems aged 4.5 years from the UNESP/Bauru plantation (Figure 1a and 1b). A priori, the residues come from the bamboo waste of the research work of design students of UNESP, basically branches and the stem apical part, which are rich in fiber. The mechanical properties of bamboo are directly related to the amount of moisture in the stems, age, and density, but mostly by the amount of fibers that ensure its resistance $[10,16]$.

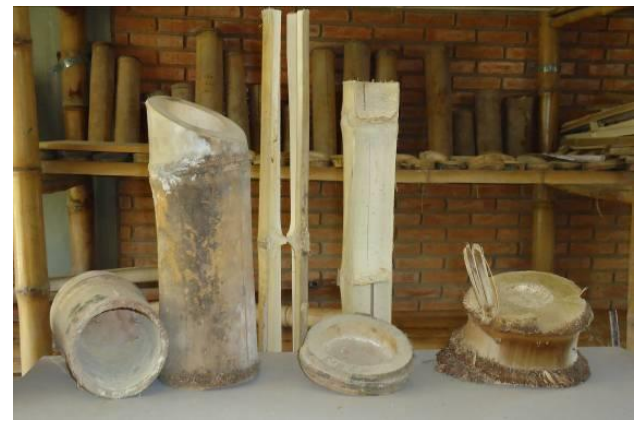

(a)

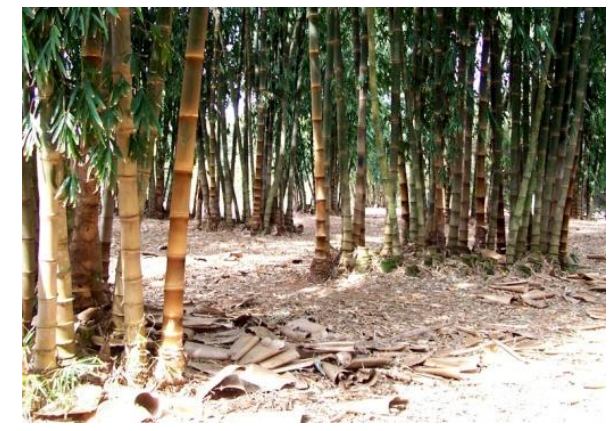

(b)

Figure 1: (a) Bamboo Culms (Laboratory UNESP / FEB), (b) plantation of Dendrocalamus giganteus at UNESP/Bauru.

The adhesives selected for the production of particleboard were: urea-formaldehyde (UF), reference PB 5070 Hexion industries, the adhesive amount was determined based on the dry weight of the wood particles, which may vary in the range of 5 to $10 \%[11,13]$; and a castor oil based adhesive $(\mathrm{M})$, consisting of two parts of polyol Lecopol F 0911 and one part of pre-polymer (isocyanate) Lecopol D 092, in mass. Table 1 shows the composition of the materials for the production of the particleboards with four different percentages $6 \%, 8 \%$, $10 \%$ and $12 \%$ for each adhesive.

Table 1: Composition of particleboard with UF and castor oil based adhesive $\mathrm{M}$

\begin{tabular}{|c|c|c|c|c|c|c|c|c|}
\hline $\begin{array}{c}\% \text { Adhesive } \\
\text { Material }\end{array}$ & $\begin{array}{l}\text { UF1 } \\
6 \%\end{array}$ & $\begin{array}{l}\text { UF2 } \\
8 \%\end{array}$ & $\begin{array}{l}\text { UF3 } \\
10 \%\end{array}$ & $\begin{array}{l}\text { UF4 } \\
12 \%\end{array}$ & $\begin{array}{l}\text { M1 } \\
6 \%\end{array}$ & $\begin{array}{l}\text { M2 } \\
8 \%\end{array}$ & $\begin{array}{c}\text { M3 } \\
10 \%\end{array}$ & $\begin{array}{c}\text { M4 } \\
12 \%\end{array}$ \\
\hline Bamboo particles (g) & 1,600 & 1,600 & 1,600 & 1,600 & 1,600 & 1,600 & 1,600 & 1,600 \\
\hline UF $(g)$ & 96 & 128 & 160 & 192 & nu & nu & nu & nu \\
\hline Water $(\mathrm{g})$ & 4.8 & 6.4 & 8.0 & 9.6 & $\mathrm{nu}$ & nu & $\mathrm{nu}$ & $\mathrm{nu}$ \\
\hline Paraffin emulsion (g) & 24.0 & 24.0 & 24.0 & 24.0 & $\mathrm{nu}$ & nu & $\mathrm{nu}$ & $\mathrm{nu}$ \\
\hline Ammonium sulfate (g) & 1.44 & 1.92 & 2.40 & 2.88 & $\mathrm{nu}$ & $\mathrm{nu}$ & nu & $\mathrm{nu}$ \\
\hline Polyol (g) & nu & $\mathrm{nu}$ & $\mathrm{nu}$ & $\mathrm{nu}$ & 64.0 & 85.3 & 106.7 & 128.0 \\
\hline Pré-polymer (g) & nu & $\mathrm{nu}$ & $\mathrm{nu}$ & nu & 32.0 & 42.7 & 53.3 & 64.0 \\
\hline
\end{tabular}

nu: not used in the composition 


\subsection{Method}

The particles of bamboo were obtained with a slicer model 683 Marconi following the procedures of $[2, \underline{3,} \underline{12}$, 15, 19]. These particles were then sieved through meshes of $4.0 \mathrm{~mm}$ and $1.2 \mathrm{~mm}$ [15]. The particles larger than $1.2 \mathrm{~mm}$ and smaller than $4.0 \mathrm{~mm}$ are called coarse; and smaller than $1.2 \mathrm{~mm}$ are called fine. Each particleboard consists of $80 \%$ coarse, and $20 \%$ fine particles, resulting in an average density of $650 \mathrm{~kg} / \mathrm{m}^{3}$.

It was used a digital scale model Marte $550 \mathrm{C}$ with a resolution of $0.01 \mathrm{~g}$ for the preparation of adhesives. The components of UF adhesive were mixed in the following order: water; ammonium sulfate; paraffin, to form a paste; and finally UF (to obtain homogeneity). Castor oil based adhesive was composed of polyol and prepolymer which were mix in amounts shown in Table 1, using a horizontal drum mixer with rotating blades (Figure 2a), model manufactured in the Mechanical Engineering Laboratory at UNESP Bauru, with 5 minute pulse. The mixture was removed and brought to a square shape with dimensions of $45 \mathrm{x} 45 \mathrm{~cm}$, randomly distributed for shaping the mattress. This mattress was pre-pressed under $0.1 \mathrm{MPa}$. A hydraulic press PHS model PHH80T was used to manufacture the panels (Figure 1b), with temperatures of $130^{\circ} \mathrm{C}$ for UF and $70^{\circ} \mathrm{C}$ for $\mathrm{M}$ (castor oil based adhesive ) and a specific pressure of $4 \mathrm{MPa}$ during ten minutes. After fabrication, the particleboards were put into a cooling chamber model Marconi MA 835UR (Figure 1c), with a constant temperature of $25^{\circ} \mathrm{C}$ and $65 \%$ relative humidity, during 72 hours, for full cooling and adhesive curing. After that, the samples were cut for physical and mechanical tests following the standard [2].

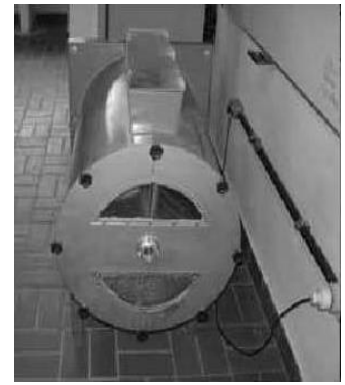

(a)

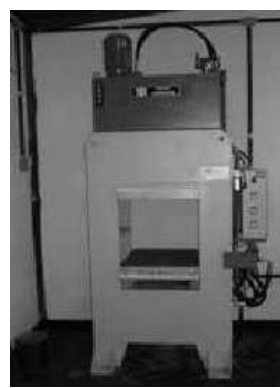

(b)

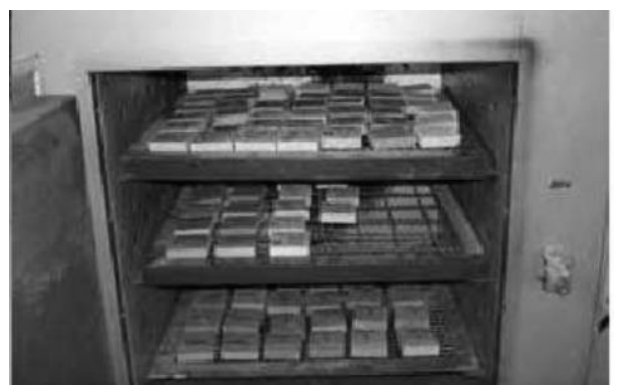

(c)

Figure 2: Equipment used in panel production: mixer (a); hydraulic press (b); cooling chamber (c).

Then, the samples were tested for: physical density; thickness swallowing and water absorption, both for $2 \mathrm{~h}$ and 24h; modulus of elasticity (MOE) and modulus of rupture (MOR) in static bending. All tests followed the standard [2]. The number of samples and their dimensions by test are presented in Table 2, according to the standard $[2,3]$.

For the thickness swallowing and water absorption the samples were immersed in a recipient with distillated water at $20^{\circ} \mathrm{C}$ with $25 \mathrm{~mm}$ of water depth during $2 \mathrm{~h}$ and $24 \mathrm{~h}$. For the thickness swallowing the measures were taken from the center of the sample with a digital micrometer model Mitutoyo. For the water absorption test, the samples were weighed during $2 \mathrm{~h}$ and $24 \mathrm{~h}$ using a digital scale.

For MOE and MOR tests, the samples were put in a universal testing machine EMIC Model DL 30,000, supported with a span of $200 \mathrm{~mm}$ and with a gradual introduction of an increasing load in the middle point of the span.

Table 02: Number of samples and dimensions by test

\begin{tabular}{ccc}
\hline Test & $\mathrm{N}^{\circ}$ of samples & Dimensions $(\mathrm{mm})$ \\
\hline $\mathbf{P}$ & 10 & $50 \times 50 \times 12.7$ \\
$\mathbf{I}_{\mathbf{2 h}}$ and $\mathbf{I}_{\mathbf{2 4 h}} ; \mathbf{A}_{\mathbf{2 h}}$ and $\mathbf{A}_{\mathbf{2 4 h}}$ & 10 & $25 \times 25 \times 12.7$ \\
MOR/MOE & 10 & $250 \times 50 \times 12.7$ \\
\hline
\end{tabular}

Note: $\rho$ is the density of the samples in $\mathrm{kg} / \mathrm{m}^{3}$

$\mathrm{I}_{2 \mathrm{~h}} ; \mathrm{I}_{24 \mathrm{~h}}$ is the thickness swelling after $2 \mathrm{~h}$ and $24 \mathrm{~h}$, respectively in percentage.

$\mathrm{A}_{2 \mathrm{~h}} ; \mathrm{A}_{24 \mathrm{~h}}$ is the absorption of water after $2 \mathrm{~h}$ and $24 \mathrm{~h}$, respectively in percentage.

MOR is modulus of rupture (MPa)

MOE is modulus of elasticity (MPa)

The analyses of each property values were made using a mean comparison by Turkey test, at $95 \%$ probability. 


\section{RESULTS AND DISCUSSION}

The mean values for physical and mechanical properties: density, thickness swallowing ( 2 and $24 \mathrm{hs}$ ), water absorption (2 and 24hs), MOR and MOE are presented in Table 3.

Table 3: Mean values of physical and mechanical properties

\begin{tabular}{ccccccccc}
\hline $\mathrm{CP}$ & UF1 & UF2 & UF3 & UF4 & M1 & M2 & M3 & M4 \\
\hline$\rho[\mathrm{kg} / \mathrm{m} 3]$ & 610.68 & 646.37 & 630.74 & 667.00 & 679.08 & 616.51 & 705.29 & 641.38 \\
$\mathrm{I}_{2 \mathrm{~h}}[\%]$ & 12.63 & 3.91 & 3.00 & 3.49 & 14.53 & 8.66 & 6.62 & 5.52 \\
$\mathrm{I}_{24 \mathrm{~h}}[\%]$ & 17.24 & 10.18 & 8.58 & 7.82 & 22.69 & 15.29 & 13.53 & 8.17 \\
$\mathrm{~A}_{2 \mathrm{~h}}[\%]$ & 60.64 & 19.59 & 15.70 & 15.52 & 51.03 & 46.00 & 29.31 & 40.46 \\
$\mathrm{~A}_{24 \mathrm{~h}}[\%]$ & 74.37 & 68.74 & 48.23 & 43.73 & 74.14 & 80.65 & 58.84 & 63.73 \\
$\mathrm{MOR}[\mathrm{MPa}]$ & 2.43 & 6.69 & 7.48 & 9.86 & 3.73 & 4.55 & 4.76 & 5.64 \\
$\mathrm{MOE}[\mathrm{MPa}]$ & 677.74 & 1308.57 & 1515.55 & 1750.26 & 351.11 & 659.04 & 711.14 & 757.30 \\
\hline
\end{tabular}

\subsection{Density}

The density of the particleboards made with castor oil based adhesive showed an average density higher than UF adhesive. Comparisons of mean densities showed differences between the traces for M2/M3, and M3/M4. The other traces showed no statistically significant difference between means. According to the results the trade M1 (castor oil 6\%) is the most economical, since the average density was $680 \mathrm{~kg} / \mathrm{m}^{3}$.

It should be highlight that experimental procedure influences directly the results, once it was developed on a laboratory scale. According to [9] who worked with Pinus wood also found density variation between target and actual density of particleboard produced in the laboratory scale.

\subsection{Thickness Swelling}

The standard [2] determines a percentage of $8 \%$ as a maximum acceptable value for thickness swelling for 2 hours immersion in water. Thus, traces containing $8 \%, 10 \%$ and $12 \%$ of adhesive satisfying this condition. The higher amount of adhesive content decreases the thickness swelling, making the particleboard less susceptible to moisture. It was observed that the particleboards M1 and UF1 with 6\% of adhesive had swell values above the maximum recommended. The work of [4] which used wastes from urban tree species and castor oil based adhesive $16 \%$ showed values of $4.95 \%$ to $5.58 \%$ in the same range of M4 (castor oil $12 \%$ ). In the particleboards produced with bamboo waste and UF $10 \%$ in [18] the average thickness swelling for $2 \mathrm{~h}$ range from $11 \%$ to $13.4 \%$ and for $24 \mathrm{~h}$ range from $14 \%$ to $16.5 \%$, only UF1 and M1 have inferior performance compared with [18]. Only traces UF2, UF3, UF4 and M4 are not statistically different.

\subsection{Water Absorption}

The standard [2] has no reference value for water absorbing. However, [15] shows the values of water absorption for medium density particleboards, obtained from Brazilian industries of particleboards that employ Pinus and Eucalyptus, which had an average value of $12 \%$ and $16 \%$ for water absorption in $2 \mathrm{~h}$, respectively. Comparing those data with this research, only traces UF3 and UF4 showed water absorption values similar to [15] with $15.70 \%$ to $15.52 \%$ respectively. The remaining traces showed higher values than those of commercial particleboards.

The water absorption for 24 hours for the particleboards M2 had the higher value (80.65\%). Comparing these values with industrialized particleboards $[15]$ for 24 hours it appears that there is great variation, since the industrialized Pinus particleboard showed average absorption of $26 \%$ while Eucalyptus showed absorption average of 50\%. Only traces UF3 and UF4 have no statistics difference and showed absorption values in the same range of Eucalyptus industrialized particleboard and in [18].

\subsection{MOR and MOE}

Table 3 shows a trend of increasing values of MOR when the adhesive content is increased. This tendency is more pronounced when using UF, and more evident when the adhesive content increased from $6 \%$ to $8 \%$. For the adhesive castor oil based adhesive the increasing tendency is more evenly. In this way all traces are statistic different. The UF particleboards had superior results in contrast to M particleboards. 
The standard [2] recommends $18 \mathrm{MPa}$ for MOR values to particleboard for structural use. None of the traits reached such magnitude, since only trace UF4 reached $9.86 \mathrm{MPa}$, indicating the utilization of the particleboards produced in this study for non structural use.

In order to improve these values in further studies is suggested to increase the size of the Bamboo particles and to mix with other residues, because the particleboards produced in this study used particles with dimensions between $4.0 \mathrm{~mm}$ and $1.2 \mathrm{~mm}$. Since the results obtained in [18] which used bamboo waste with planer waste and chips of wood (wood waste) and in [9] which used particles of coconut fiber with $7 \mathrm{~mm}$ of dimension attained better results. However, in the cited study the particleboards can be classified as high density $\left(801-873 \mathrm{~kg} / \mathrm{m}^{3}\right)$, therefore more resistant. The particleboards produced in [7] obtained values for MOR between $51.63 \mathrm{kgf} / \mathrm{cm}^{2}(5.06 \mathrm{MPa})$ and $99.16 \mathrm{kgf} / \mathrm{cm}^{2}(9.72 \mathrm{MPa})$, made from pine residues with density between 0.6 and $0.7 \mathrm{~g} / \mathrm{cm}^{3}$ and UF adhesive in the levels of $4 \%, 8 \%$ and $12 \%$. The traces UF2, UF3 and UF4 showed similar variation of 6.69 to $9.86 \mathrm{MPa}$.

It is noted two distinct groups regarding the values of modulus of elasticity (MOE). The superior group are compost of UF2, UF3 and UF4 (these were not significantly different from each other); and inferior group M1, M2, M3, M4 and UF1 (these were not significantly different from each other). Thus, is recommended the use of trace UF2 considering the cost-benefit of additional percentage of adhesive versus MOE.

\section{FINAL CONSIDERATIONS}

The castor oil polyurethane based adhesive did not meet the expectations of being more efficient than the traditional urea-formaldehyde adhesive, for particleboards made of bamboo waste with particles range from $4.0 \mathrm{~mm}$ to $1.2 \mathrm{~mm}$, but showed its feasibility to be used as adhesive with this kind of raw material.

In physical assessment the urea formaldehyde adhesive performed better on all properties, mainly related to thickness swelling and water absorption, which are important requisites for the classification of particleboards for external use, i.e., exposed to moisture. In mechanical evaluation urea-formaldehyde adhesive also performed better than castor oil based adhesive. In bending, both MOR and MOE, the urea formaldehyde adhesive showed superior resistance to castor oil based adhesive, with MOR reaching the value of 9.86 $\mathrm{MPa}$ for $12 \%$ of UF and $5.64 \mathrm{MPa}$ for $12 \%$ of castor oil based adhesive. However, none reached the value recommended by the Brazilian standard [2] of $18.0 \mathrm{MPa}$ and CS 236 (66) standard of $112 \mathrm{kgf} / \mathrm{cm}^{2}(10.98$ $\mathrm{MPa}$ ), for structural usage. The MOE reached $1750.26 \mathrm{MPa}$ for $12 \%$ of UF and $757.14 \mathrm{MPa}$ for $12 \%$ castor oil based adhesive.

Due to results attained for MOR e MOE, the particleboards produced in this study indicate its non-structural use, i.e., liners, partitions and other uses for internal seal (due to the results of water absorption and thickness swallowing), which does not requires a high resistance.

This indicates the Bamboo wastes are a technically feasible alternative for use in particleboard production with both adhesives, provided they respected their resistance characteristics, and also their physical results are in accordance with the results obtained in [18] for the bamboo species Bambusa balcooa and Bambusa vulgaris and for particleboards of wood [7]. In [18] with used bamboo wastes with wood waste (planer and chips) bonded with castor oil based adhesive the mechanical results are far superior, but the particleboards could not be considered of medium density $\left(\rho>800 \mathrm{~kg} / \mathrm{m}^{3}\right)$. For further studies it is suggested the used of bamboo particles with large dimensions and with other kind of residues in order to improve its mechanical properties.

\section{ACKNOWLEDGMENTS}

The authors thank FAPESP - Foundation for Research Support of the State of São Paulo for supporting this research, process number 07/59434-9.

\section{REFERENCES}

[1]Alves, L. S.; Silva, S. A. M.; Azambuja, M. A.; Varanda, L. D.; Christoforo, A. L.; Rocco, F. A. L. Particleboard produced with sawmill waste of different wood species. Advanced Materials Research (Online), v. 884-885, p. 689-693, (2014).

[2] Associação Brasileira de Normas Técnicas. NBR 14810 - Chapa de madeira aglomerada. Parte 2: requisitos. ABNT. Rio de Janeiro, (2006). 
[3] Associação Brasileira de Normas Técnicas. NBR 14810 - Chapa de madeira aglomerada. Parte 3: métodos de ensaio. ABNT. Rio de Janeiro, (2006).

[4] Bertolini, M. S.; Nascimento, M. F.; Blecha, K. A.; Lahr, F. A. R. Eco-panels on waste from Urban Trees and Castor oil Polyurethane Resin. International Journal of Agriculture and Forestry, v. 3(1), p. 12-15, (2013). DOI:10.5922/j.ijaf.20130301.03.

[5] Biswas, D.; Bose, S. K.; Hossain, M. M. Physical and mechanical properties of urea formaldehydebonded particleboard made from bamboo waste. In: International Journal of Adhesion and Adhesives, Volume 31, Issue 2, p. 84-87, (2011), DOI: 10.1016/j.ijadhadh.2010.11.006.

[6] Czarnecki. R.; Dziurka. D.; Lecka. J. The use of recycled boards as the substitute for particleboard in the centre layer of particleboards. Electronic Journal of Polish Agricultural Universities. Wood Technology. v. 6. n. 2., (2003).

[7] Dacosta. L. P. E. et al. Qualidade das chapas de partículas aglomeradas fabricadas com resíduo do processamento mecânico da madeira. Ciência Florestal. Santa Maria. v. 15. n. 3. p. 311-322. (2005).

[8] Fiorelli, J. ; Sartori, D. L.; Cravo, J. C. M.; Savastano Jr, H.; Rossignolo, J. A; Nascimento, M. F.; Lahr, F. A. R. . Sugarcane bagasse and castor oil polyurethane adhesive-based particulate composite. Materials Research (São Carlos. Impresso), v. 16, p. 439-446, (2013).

[9] Fiorelli, J.; Curtolo, D. D.; Barrero, N. G.; Savastano Jr., H.; Pallone, E. M. A.; Johnson, R. Particulate composite based on coconut fiber and castor oil polyurethane adhesive: An eco-efficient product. Industrial Crops and Products, V. 40, p 69-75, (2012).

[10] International Network for Bamboo and Rattan (INBAR). Priority species of bamboo and rattan. New Delhi. India : INBAR IDRC. 68p. (1994).

[11] Iwakiri. S.; Silva. J. R. M. Da; Matoski. S. L. S.; Leonhadt. G.; Caron. J. Produção de chapas de madeira aglomerada de cinco espécies de pinus tropicais. Floresta e Ambiente. v. 8. n.1. p.137 - 142, (2001).

[12] Iwakiri. S. et al. Produção de painéis de madeira aglomerada de alta densificação com diferentes tipos de adhesiveas. Scientia Florestalis. São Paulo, n. 68, p. 39-43, (2005).

[13] Kollmann. F. F. P.; Kuenzi. E. W.; Stamm. A. J. Principles of wood science and technology II - wood based materials. New York: Springer-Velarg, (1975).

[14] Maloney. T. M. Modern particleboard \& dry process fiberboard manufacturing. 2.ed. Sao Francisco: Miller Freeman, (1993).

[15] Nascimento. M. F. Chapas de partículas homogêneas - madeiras do nordeste do Brasil, 145p. Tese (Doutorado) - Escola de Engenharia de São Carlos. Universidade de São Paulo. São Carlos. (2003).

[16] Pereira. M. A. R.; Beraldo. A. L. Bambu de corpo e alma. 1.ed. Bauru: Canal 6 Editora. 240p. (2008).

[17] Santos, M. F. N.; Battistelle, R. A. G.; Bezerra, B. S.; Varum, H. S. A. Comparative study of the life cycle assesment of particleboards made of residues from sugarcane bagasse (Saccharum spp.) and pine wood shavings (Pinus ellioti). In: Journal of Cleaner Production, v.64, p. 345-355, (2014).

[18] Silva, D. A. P. L.; Varanda, L. D.; Christoforo, A. L.; Rocco, F. A. L. Addition of Impregnated Paper Residue to Produce MDP Wood Panel: Example of Solid Waste Recycling. In: International Journal of Materials Engineering, v. 2, p. 75-79, (2012).

[19] Yano. H. et al. Effects of element size and orientation in the production of hight strength adhesive impregnated wood based materials. Holzforrschung. Germany. v. 54. n. 4. p. 443-447. (2000).

[20] Rivela, B.; Hospido, A.; Moreira, M. T.; Feijoo, G. Life Cycle Inventory of Particleboard: A Case Study in the Wood Sector. In: JLCA, v. 11 (2), (2006). DOI: 10.1065/lca2005.05.206. 